\title{
\%ICFBE 2021
}

The 5th International Conference on Family Business and Entrepreneurship

\section{THE INFLUENCE OF ENTREPRENEURSHIP EDUCATION TOWARDS ENTREPRENEURIAL INTENTION MEDIATED BY ATTITUDE, SUBJECTIVE NORMS, AND PERCEIVED BEHAVIORAL CONTROL OF BUSINESS MANAGEMENT STUDENTS AT UNIVERSITAS CIPUTRA SURABAYA}

\author{
Cynthia Hartono $^{1}$, Wendra Hartono ${ }^{2 *}$, Charly Hongdiyanto ${ }^{3}$, Gracia \\ Ongkowijoyo ${ }^{4}$ \\ 1,2,3,4 Universitas Ciputra, Surabaya \\ Corresponding author: wendra.hartono@ciputra.ac.id
}

\begin{abstract}
One of the major problems in Indonesia is inadequate number of workers with the number of job positions available. Hence, it is better for people with productive age, especiallythe one that is educated, to have an orientation or intention to create job, rather than being a job seeker. Entrepreneurship education is considerably believed to be a prominent element informing one's entrepreneurial intention. Nevertheless, many studies show few consistent results on the direct impact of entrepreneurship education on individual's entrepreneurial intention. Therefore, the aim of this study is to examine the influence of entrepreneurship education toward entrepreneurial intention with Theory of Planned Behaviour (TPB) approachas a mediator. This theory clarified that there are three primary forces that influence an individual's intentions, which are attitude, subjective norms, and perceived behavioural control. The approach to this research is quantitative method, where the data collected will be analysed statistically using PLS-SEM. The researcher selected the population of 992 businessmanagement students at Universitas Ciputra Surabaya, who are registered in the academic year of 2017 and 2018. By using purposive sampling method, the total samples that successfullycollected are 305 samples. The result of this study concludes that the direct relationship betweenentrepreneurship education to entrepreneurial intention shows no significant effect. Nevertheless, entrepreneurship education can significantly influence entrepreneurial intentionif it is fully mediated by attitude toward entrepreneurship, subjective norms, and perceived behavioural control.
\end{abstract}

Keywords: Entrepreneurship Education, Attitude towards Entrepreneurship, Subjective Norms, Perceived Behavioural Control, Entrepreneurial Intention

1. Introduction

The slow movement of the economy has had an impact on the Indonesian labor sector. The Central Statistics Agency (BPS) recorded that in the period of 6 months in 2019, the unemployment rate in Indonesia is increased by 230,000 people. This occurs as there is inadequate number of workers with the number of job positions available, while the number ofunemployed people is still growing. The increase in unemployment in Indonesia can be a potential time bomb in the middle of world economic recession threat. With the fourth largestpopulation in the world and a high population of productive age, high unemployment rate canbe a 
barrier to the use of demographic bonus. Hence, it is better for people with productive age,especially the one that is educated, to have an orientation or intention to create job, rather thanbeing a job seeker.

To create job means to become an entrepreneur. Entrepreneurship has been a tool to create jobsand generate country's economic growth (Kshetri, 2018, p. 17). It is proven by many countrieswith good economic conditions have a large entrepreneurial rank. According to the data from Global Entrepreneurship and Development Institute, Indonesia is in the rank of 94 out of 197 countries, which indicates that Indonesia has low GEI. Low GEI means that theeconomic growth of a country is also low. Therefore, become an entrepreneur is the solution to help the economic growth and reduce unemployment rate in Indonesia (Kshetri, 2018).

The way to achieve that solution is to plant entrepreneurial intention to people at productive age in Indonesia, especially college students. In response to this phenomena, Ir. Ciputra decidedto build Universitas Ciputra Surabaya where it can be a place to forge entrepreneur generation.It is in West Surabaya, Indonesia, and was founded in 2006 to help Indonesia to createand support world class entrepreneurs in the future. The most important program at Universitas Ciputra Surabaya regarding entrepreneurship education is Entrepreneurship (E) subject, which being given to every major. Universitas Ciputra Surabaya has commitment to equip every student to be able to become an entrepreneur according to their respective expertise. Theories and practices through project-based learning about entrepreneurship are given equally in Entrepreneurship (E) subject that is received by students from the very first semester until sixthsemester. Entrepreneurship education is considerably believed to be a prominent element in forming one's entrepreneurial intention (Do Paco et al, 2011, in Zhang et al, 2019). Nevertheless, manystudies show few consistent results on the direct impact of entrepreneurship education on individual's entrepreneurial intention. Hence, the Theory of Planned Behavior by Ajzen (1991) is being used as a mediation approach between entrepreneurship education and entrepreneurial intention (Zhang et al., 2019; Bui et al., 2020). The theory clarified that there are three primary forces that influence an individual's intentions, which are attitude toward behavior, subjective norm and perceived behavioral control.

The novelty in this research is to figure out what the relevancy between education entrepreneurand business behavior on behalf to create world class entrepreneur. This research is conductedto give insight and feedback to Universitas Ciputra Surabaya for better improvement on the entrepreneurship education process.

\section{Literature Review}

Entrepreneurship education (EE) is the way of developing or adding skills and knowledge toidentify business opportunities in pursuing a career as an entrepreneur (Souitaris et al., 2007,in Puni et al., 2018). According to Gerba, D.T. (2012) in Utami (2017), EE is a deliberate attempt by people to raise awareness of entrepreneurship. It is about how we learn to examinethe possibilities and uncertainties in facing the business world (Utami, 2017). It is widely believed to be a prominent element in forming one's entrepreneurial intention (Do Paco et al.,2011, in Zhang et al., 2019). This is because education for entrepreneurship focuses on enhancing entrepreneurial awareness, skills, and abilities, as well as entrepreneurial intention and behaviour that are appropriate to the needs of the economy (Sun et al.,2017). The more entrepreneurship education courses expose students to general entrepreneurial knowledge and improve their ability to identify opportunities in their environments, the greater the likelihoodfor them to develop intentions to participate in entrepreneurial activities (Puni et al., 2018). Hence, the hypothesis proposed in this study is:

H1: Entrepreneurship education significantly influences entrepreneurial intention ofbusiness management student at Universitas Ciputra Surabaya.

While entrepreneurial intention (EI) defines a person's belief as self-recognizing that they intend to establish or build a new business venture and aim to do so consciously at some pointin the future (Thompson, 2009, in Zhang, et al., 2019). In becoming an entrepreneur, it is important to have EI. It is the ambition of people to take the opportunity to open their own business by developing a product or new service (Utami, 2017). It is a mind that stimulates people to make businesses (Rasli, et al., 2013, in Utami, 2017).

Theory of Planned Behavior (TPB), which developed by Ajzen (1988), stated about intention toward certain behaviors are actually the result of 3 antecedents, which are attitude toward behavior, subjective norms, and perceived behavioral control (Zhang et al., 2019; Bui et al., 2020; Luc, 2020). Therefore, TPB is believed to be a prominent academic model or frequentlyused model for analyzing and understanding factors that influence individual's intention to entrepreneurial behavior (Farooq et al., 2018). For more than 20 years, TPB has been used to evaluate the effect of EE on EI (Sun et al., 2017). This is because the future behavior of individuals is the outcome of their intention, or it might be assumed that stronger intentions 
contribute to stronger behavioral involvement in particular activities (Paray \& Kumar, 2020).

Attitude refers to the personal values believed by individuals regarding any particular object orbehavior (Ajzen, 1991, in Farooq et al., 2018). It is a positive or negative evaluation or assessment of behavior by an individual, which is originated from previous knowledge and experiences that have been formed throughout the life. (Kuehn, 2008, in Zhang et al., 2019; Lu\& Wang, 2018). Entrepreneurship education plays an important role in cultivating a positive attitude towards entrepreneurship (Zhang et al., 2019). This is because entrepreneurial attitudeis more flexible than other traits of personality and can be altered by educators or practitioners(Schwarz et al, 2009 in Zhang et al, 2019).

While subjective norms are a function based on a belief called normative belief, which is a belief about agreement or disagreement that comes from significant others (people or groups that affect individuals), such as parents, spouse, close friends, coworkers or others towards a certain intention (Ajzen, 1991, in Farooq et al., 2018; Phan, 2018). Research indicates that entrepreneurial learning plays a significant role in the creation of a subjective norm for entrepreneurial behavior that leads to entrepreneurial intention (Basu \& Virick, 2008; Souitariset al, 2007, in Zhang et al, 2019). This is because students' subjective norm can be increased through entrepreneurship education, as it enables a community of classmates that have the same entrepreneurial minded. It creates a network of mutual support from which individuals can receive support from their mentors, lecturers, and classmates.

Lastly, perceived behavioral control defines as individual's believes about how far they are capable of performing a given action or have control over it. When a task is seen as very easyto execute, there is a high chance of that individuals will execute that task, which in this case is entrepreneurship (Ajzen, 1991, in Farooq et al., 2018). Entrepreneurship education normally equips students with entrepreneurial knowledge, skills, and competencies (Galloway and Brown, 2002; Wilson et al, 2007, in Zhang et al, 2019), which those factors can make studentsmore confident toward their intention to become an entrepreneur (Do Paco et al, 2011, in Zhanget al, 2019). This means that the greater the PBC, the stronger the intention of individual to start building a business (Zhang et al., 2019). Hence, the hypotheses proposed in this study are:

H2: Entrepreneurship education significantly influences attitude toward entrepreneurship of business management student at Universitas Ciputra Surabaya.

H3: Entrepreneurship education significantly influences subjective norms of business management student at Universitas Ciputra Surabaya.

H4: Entrepreneurship education significantly influences perceived behavioural controlof business management student at Universitas Ciputra Surabaya.

Personal attitude is then accountable for the like or disliking of individual and, as a result, it increases the chances of undertaking a particular behavior, which in this case is entrepreneurialactivities (Robinson, et al., 1991, in Farooq, et al., 2018). Moreover, advice from parents, spouse, colleagues, and friends will be the essential factor for individuals in choosing their career path. In this way, opinions from significant others may be influential in initiating entrepreneurial intentions for potential entrepreneurs (Farooq et al, 2018). Furthermore, perceived behavioural control represents beliefs that control over an entrepreneurial intention, as it contributes to behaviour in terms of entrepreneurial abilities, knowledge, resources, or opportunity (Sun et al., 2017). This factor refers to the perceived capability or self-efficacy ofa person to perform entrepreneurial behaviours (Sun et al., 2017). A strong sense of self- confidence that people have in themselves towards the knowledge, abilities, and skills to do something, it will strengthen their desire to do particular intention. Hence, the hypotheses proposed in this study are:

H5: Attitude toward entrepreneurship significantly influences entrepreneurial intentionof business management student at Universitas Ciputra Surabaya.

H6: Subjective norms significantly influence entrepreneurial intention of business management student at Universitas Ciputra Surabaya.

H7: Perceived behavioural control significantly influences entrepreneurial intention ofbusiness management student at Universitas Ciputra Surabaya.

\section{Research Method}

The approach to this research is quantitative method, where the data will be analyzed statistically using Partial Least Square-Structural Equation Modelling (PLS-SEM) technique that uses SmartPLS 3 as the software program. The researcher collects the data by distributinga questionnaire to the respondents directly using purposive (judgement) sampling. The researcher has selected the population of 992 business management students at Universitas Ciputra Surabaya, who are registered in the academic year of 2017 and 2018. By using the Slovin formula with 5\% error margin, the total sample is rounded to 300 people. The researchercollects the data by distributing a questionnaire to the respondents directly using purposive 
(judgement) sampling. This method of sampling is restricted to categories of subjects that are in the perfect situation to provide the needed or necessary information, either because they arethe only ones who have it, or because they meet certain requirements that set by the researcher(Sekaran \& Bougie, 2016). The requirements of the purposive sampling will be concentrated on characteristics, which are:

1. Respondents must be business management students at Universitas Ciputra Surabaya who are registered in the academic year of 2017 and 2018.

2. Respondents must have been learned about entrepreneurship education for atleast 4 semesters through Entrepreneurship (E) subject.

3. Respondents are still currently doing / running their business project or familybusiness The researcher managed to collect as many as 330 samples, in which 25 samples had to be deleted because they did not meet the purposive sampling criteria as set by the researcher. Theage distribution of respondents from Universitas Ciputra Surabaya who filled out this survey consisted of 14 respondents (4.6\%) aged 19 years, 128 respondents $(41.9 \%)$ aged 20 years, 137 respondents $(44.9 \%)$ aged 21 years, 24 respondents $(7.9 \%)$ aged 22 years, and only 1 respondent $(0.3 \%)$ aged 23 and 24 years respectively. The data indicates that the respondents who filled out this questionnaire were students who were indeed in semester 5 and 7 , with only 2 respondents who were above the average age (23 and 24 years) due to being late in entering undergraduate education.

\begin{tabular}{ccc} 
& Table 1: Respondent Age Data & \\
\hline Age & Frequency & Percentage \\
\hline 19 & 14 & $4.6 \%$ \\
\hline 20 & 128 & $41.9 \%$ \\
\hline 21 & 137 & $44.9 \%$ \\
\hline 22 & 24 & $7.9 \%$ \\
\hline 23 & 1 & $0.3 \%$ \\
\hline 24 & 1 & $0.3 \%$ \\
\hline
\end{tabular}

Source: Processed data (2020)

The measurement of the variables will be based on the 5-point Likert Scale, which is intendedto measure how strongly subjects agree or disagree with five-point scale statements (Sekaran \& Bougie, 2016, p. 215). This research consists of 5 variables, namely entrepreneurship education, attitude toward entrepreneurship, subjective norms, perceived behavioral control, and entrepreneurial intention. Each variable is measured by several indicators and eachindicator has its operational definitions to further be measured by 5-point Likert Scale, which the details are as follows:

Entrepreneurship education (EE): The indicators for this variable are: (1) entrepreneurship education program fosters the desire of student to be an entrepreneur; (2) the presence of entrepreneurship education makes student aware of the business opportunities and ideas; (3) entrepreneurship education add knowledge to student in the entrepreneurship industry. The examples of the operational definition are: (1) I learn methods to generate basic business ideasthrough entrepreneurship education; (2) my ability to better recognize business opportunities in my surroundings is increased because of entrepreneurship education (Puni et al, 2018).

Attitude toward entrepreneurship (ATE): The indicators for this variable are: (1) interestedin the business opportunities; (2) to have a positive view about business failure; (3) to have thebravery to face business risks. The examples of the operational definition are: (1) I am interested in taking advantage of new business opportunities; (2) I believe that becoming an entrepreneur have more advantages than disadvantages (Utami, 2017).

Subjective norms (SN): The indicators for this variable are: (1) support of confidence from family in starting a business; (2) support of confidence in terms of the efforts of those who areconsidered important; (3) support of confidence from friends in the business. The examples ofthe operational definition are: (1) my motivation to open a business is driven by the encouragement of my family; (2) I find that support from my friends means a lot to me (Farooqet al, 2018).

Perceived behavioural control (PBC): The indicators for this variable are: (1) have confidenceand readiness in the ability to manage or create own business; (2) able to control the creation process of a new business; (3) fully aware of what it takes to start a new business. The examplesof the operational definition are: (1) I would have a high possibility of succeeding, if I tried tostart a business; (2) I can control the creation process 
of a new business (Farooq et al, 2018).

Entrepreneurial intention (EI): The indicators for this variable are: (1) choose the path to become an entrepreneur instead of becoming an employee; (2) have plans to start a business; (3)have strong intention and determination to establish a business in the future. The examples of the operational definition are: (1) I would rather become an entrepreneur than become an employee; (2) I have plans to open my own business in the future (Puni et al, 2018).

\section{Results and Discussion}

There are 2 types of validity test in this research, which are convergent validity and discriminant validity. According to Hair et al. (2017), convergent validity is the connection ofindicators' value with the respective variables in the study. Conversely, discriminant validity indicates that measurements of variables that should not be correlated with each other theoretically, are indeed not corresponded to each other. In the convergent validity test, it is declared valid if the value of outer loading $>0.7$ and the value of average variance extracted $(\mathrm{AVE})>0.5$. While in the discriminant validity test, it is said to be valid if the value of cross loading is greater than the cross-loading value for other variables, or with the required minimumvalue, which is $>0.7$ (Garson, 2016).

Research results show that outer loading and cross loading values are ranging from $0.569-0.824$. There are several indicators with outer loading scores $<0.7$ that are still can be kept because they are able to meet the minimum AVE requirements $(>0.5)$ for each variable in Table 2. Based on this matter, the indicators used in this study have been declared valid to measure each existing variable according to the indicator. The reliability test is necessary in this research to check whether the indicators used for this research are consistent and stable, so that they are reliable to be used. According to Hair et al.(2017), reliability measurement is carried out by using composite reliability and Cronbach's alpha. Composite reliability and Cronbach's alpha with a value of 0.6 to 0.7 can be accepted, while the value between $0.7-0.9$ are considered satisfactory (Garson, 2016). Research resultsshow that composite reliability values are ranging from 0.847 -0.895 and Cronbach's alpha values are ranging from $0.773-0.867$. Hence, it can be stated that the variables used in this study are reliable. The validity and reliability test results are presented in Table 2.

Table 2: AVE, Composite Reliability, and Cronbach's Alpha Values

\begin{tabular}{cccccc}
\hline $\begin{array}{c}\text { Variable } \\
\text { Test }\end{array}$ & $\begin{array}{c}\text { Entrepreneurship } \\
\text { Education }\end{array}$ & $\begin{array}{c}\text { Attitude toward } \\
\text { Entrepreneurship }\end{array}$ & $\begin{array}{c}\text { Subjective } \\
\text { Norms }\end{array}$ & $\begin{array}{c}\text { Perceived } \\
\text { Behavioral } \\
\text { Control }\end{array}$ & $\begin{array}{c}\text { Entrepreneurial } \\
\text { Intention }\end{array}$ \\
\hline AVE & 0.512 & 0.526 & 0.524 & 0.518 & 0.522 \\
\hline $\begin{array}{c}\text { Composite } \\
\text { Reliability }\end{array}$ & 0.880 & 0.847 & 0.867 & 0.895 & 0.883 \\
\hline $\begin{array}{c}\text { Cronbach's } \\
\text { Alpha }\end{array}$ & 0.840 & 0.773 & 0.822 & 0.867 & 0.844 \\
\hline
\end{tabular}

Source: Processed data (2020)

Structural model (inner model) test is assessed using coefficient of determination $\left(\mathrm{R}^{2}\right)$ and thevalue of $\mathrm{t}$ statistic through bootstrapping results (Garson, 2016). T-statistic shows the significance of the relationship between variables in the study, while $\mathrm{R}^{2}$ is used for measuringthe percentage of an endogenous latent variable that is defined by its exogenous latent variable(Hair et al., 2017). The result of the structural model test of this research model is presented inFigure 2.

From Figure 2, it is shown that t-statistic values between variable EE and EI, EE and ATE, EEand SN, and $\mathrm{EE}$ and $\mathrm{PBC}$ are $0.752,5.471,6.403,10.672$ respectively. Meanwhile, the $\mathrm{t}-$ statistic values of mediation variables to dependent variable, which are ATE to EI, SN to EI, and PBC to EI, are 6.434, 2.443, 3.142 respectively. T-statistic value of $>1.96$ shows that thereis significance relationship between variables in the study (Hair et al., 2017). 


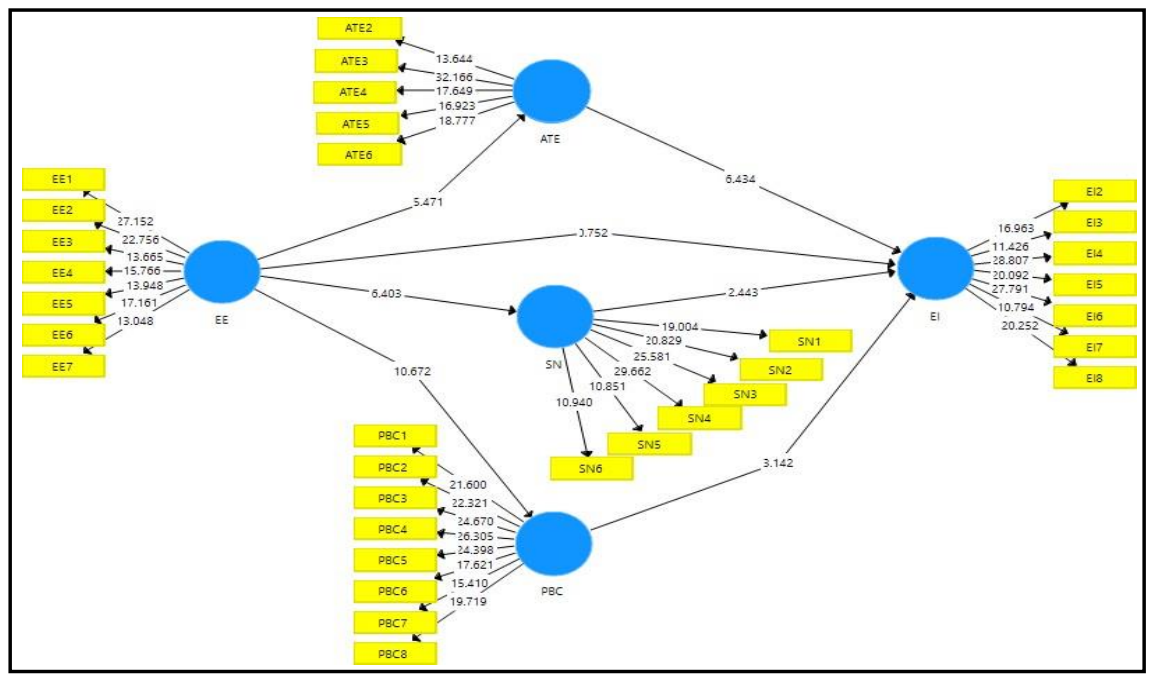

Figure 1: Inner Model Test

(Source: Processed data, 2020)

Therefore, all ofthe hypotheses are accepted, except H1. The detail of the value of path coefficient in this research model is presented in Table 3.

Table 3: Path Coefficient

\begin{tabular}{cccccc}
\hline \multicolumn{1}{c}{ Variable } & $\begin{array}{c}\text { Original } \\
\text { Sample (O) }\end{array}$ & $\begin{array}{c}\text { Sample Mean } \\
(\mathbf{M})\end{array}$ & $\begin{array}{c}\text { Standard } \\
\text { Deviation } \\
\text { (STDEV) }\end{array}$ & $\begin{array}{c}\text { T-Statistics } \\
(\mid \mathbf{O} / \text { STDEV } \mid)\end{array}$ & P Values \\
\hline EE -> EI & 0.039 & 0.040 & 0.052 & 0.752 & 0.453 \\
\hline EE -> ATE & 0.361 & 0.369 & 0.066 & 5.471 & 0.000 \\
\hline EE -> SN & 0.427 & 0.433 & 0.067 & 6.403 & 0.000 \\
\hline EE -> PBC & 0.534 & 0.544 & 0.050 & 10.672 & 0.000 \\
\hline ATE -> EI & 0.453 & 0.457 & 0.070 & 6.434 & 0.000 \\
\hline SN -> EI & 0.120 & 0.121 & 0.049 & 2.443 & 0.015 \\
\hline PBC -> EI & 0.201 & 0.203 & 0.064 & 3.142 & 0.002 \\
\hline
\end{tabular}

Source: Processed data (2020)

Meanwhile, another structural model test is assessed by using coefficient of determination $\left(\mathrm{R}^{2}\right)$ test. The value of $\mathrm{R} 2$ varies from 0 to 1 , with a higher value showing a higher predictive accuracy level of how many percentages the dependent variable can be explained by independent variable. The values of $0.75,0.50$, or 0.25 of the dependent variables can be definedas strong, moderate, or weak (Hair et al., 2017). $\mathrm{R}^{2}$ value of ATE, SN, PBC, and EI are 0.130,0.182, 0.286, and 0.444 respectively. Based on this data, it can be interpreted that the variablesstudied are still very limited because the R2 value in each variable shows less than $50 \%$, whichmeans that there are other variables that are more influential than the variables in this study. In addition, the mediation effect test is carried out by looking at the t-statistic value in the specific indirect effect section in SmartPLS software. This is because in terms of mediation test, it is not only testing the direct effect between variables, but also the indirect effect that occurs between independent variable and dependent variable through mediation variable (Hairet al., 2017). The result of this study, which is presented in Table 4, indicates that the relationship among EE to EI mediated by ATE, SN, and PBC are all significant. Thus, it can be concluded that ATE, SN, and PBC act as full mediators in this research model.

The result of this study state that the direct relationship between EE to EI shows no significanteffect. This finding reinforces the result of previous study by Kusmintarti et al. (2017), whichit revealed that the impact of entrepreneurship education on entrepreneurial intention is not relevant due to the ineffective method of delivering the entrepreneurial learning. This researchalso reinforces the previous study by Pratana and Margunani (2019) that stated the hypothesisof there is an influence of entrepreneurship education towards 
students' entrepreneurialintention is rejected.

This can happen for several reasons. First, students at Universitas Ciputra Surabaya (UC) only fulfil their obligations in taking courses according to the curriculum and think of passing the grades or only looking for good grades, so that they are only limited to understand about entrepreneurship through the education but not to build an intention in themselves to be an entrepreneur. In addition, there are some same materials that are repeated several times in different subjects, such as SWOT analysis, external \& internal analysis, Porter's five forces, marketing mix, etc. Some subjects are also delivering the same meaning; for instance, business execution with Entrepreneurship (E) project, strategy management with internationalcorporate strategy, etc. This makes the entrepreneurship education become less effective.

Other results of this study indicate a positive and significant relationship between EE to ATE, EE to SN, and EE to PBC. This is in line with the previous studies from Zhang et al. (2019), Paray \& Kumar (2020), and Sun et al. (2017). According to Sun et al. (2017) understanding the reason of entrepreneurship (i.e. why) will raise the positive entrepreneurial attitude. This can be shown from the findings at UC that EE, especially Entrepreneurship (E) project, given to students can build students' positive ATE through the way of the lecturers, guest lecturers, and facilitators teach and inspire them. Meanwhile, students' SN can be increased through EE, as it enables a community of classmatesthat have the same entrepreneurial minded (Zhang et al., 2019). It creates a network of mutualsupport from which individuals can receive support from their mentors, lecturers, and classmates. This can be shown from the findings at UC that already executed the samethings. Through various entrepreneurial projects given from several subjects, students can expand their network with people who have the same entrepreneurial vision and mission. In addition, SN can also be enhanced by knowing the role models in entrepreneurship, and then it can be resulted in EI (Sun et al., 2017). Therefore, besides communities of people who are in the same class of EE or in the same major of business management, a good teachingmethod to build one's EI by EE through SN is needed. It can be in the form of case studies, guest speech / lecturer, and interview of successful entrepreneurs (Sun et al., 2017), which alsohas been done by UC.

Furthermore, self-efficacy, or PBC, can be increased by knowing how to do entrepreneurship (learning by doing), and then it can enhance one's EI (Sun et al., 2017). EE normally equips students with entrepreneurial knowledge, skills, and competencies (Zhang et al, 2019), which those factors can make students more confident toward their intention to become an entrepreneur (Do Paco et al, 2011, in Zhang et al, 2019). UC is well-known for its advanced entrepreneurship curriculum since students does not only learn about theories but also in the form of practices through real business projects that being mentored directly from business expert in the related industry. In addition, UC also facilitate the students whose business projectis feasible to join national and even international exhibition. This can surely equip students with a lot of experiences, entrepreneurial knowledge, skills, and competencies.

The results of this study also state that the relationship between ATE to EI, SN to EI, and PBCto EI shows positive and significant effect. This is supported by previous research by Farooqet al. (2018), Santi et al. (2017), and Sun et al. (2017). The better the student's entrepreneurialattitude, the higher his or her entrepreneurial intention. The result of this research is relevantto the study of the grand theory, namely Theory of Planned Behavior (TPB) developed by Ajzen (1988), which stated that a person's intention is influenced by personal factors, namely attitudes. Therefore, when students at UC have a positive evaluative response related toentrepreneurship, where it is gained from the education given, it will surely foster entrepreneurial intention in themselves. In addition, the greater the support from SN being provided to student, the higher the student'sEI. The result of this research is relevant to the study of the grand theory, namely Theory of Planned Behavior (TPB) developed by Ajzen (1988), which stated that subjective norms are afunction based on a belief called normative belief, which is a belief about agreement or disagreement that comes from significant others (people or groups that affect individuals), suchas parents, spouse, close friends, co-workers, or others towards a certain intention. In this way, advice and opinions from significant others may be influential in initiating EI for potential entrepreneurs (Farooq et al., 2018). This can be shown from the findings at UC that also havetheir family business as the main point of the curriculum. The family business guild at UC makes it possible for students to communicate well with their entrepreneur parents and vice versa to continue the family business. Finally, the greater the student's PBC, the stronger his or her EI. The result of this research isrelevant to the study of the grand theory, namely Theory of Planned Behavior (TPB) developedby Ajzen (1988), which stated that a strong sense of self-confidence that people have in themselves towards the knowledge, abilities, and skills to do something, it will strengthen theirdesire to do intention, which in this case is entrepreneurship. PBC is the condition where people believe about how far they can perform a given action or have control over it. Therefore, when a career to become an entrepreneur is seen as very easy to pursue, there is a high chance of that individual will execute his or her 
EI. UC facilitate their students to possess the entrepreneurial minded, knowledge, skills, and experiences through theadvanced entrepreneurship curriculum, which has its own business project and family business class. This surely will develop students' strong sense of self-confidence towards their intentionto become an entrepreneur.

Finally, EE can significantly and positively influence EI if it is mediated by ATE, SN, and PBC variables. Hence, it can be stated that entrepreneurship education cannot directly form student's entrepreneurial intention; therefore, mediators of ATE, SN, and PBC are neededso that entrepreneurship education, which is the leading curriculum at Universitas Ciputra Surabaya, can have an influence on their business management students in fostering their intention to become an entrepreneur. The result of this study is supported by Zhang et al. (2019)and Paray \& Kumar (2020) in their research results, which stated that ATE, $\mathrm{SN}$, and PBC mediate the intercourse of EE to EI.

Based on previous study by Zhang et al. (2019), students who have a positive evaluation of ATE obtained from EE will increase their tendency to have EI. In addition, social pressure through students' SN will be influenced by the environment where they take the EE, so that itcan foster their interest in entrepreneurship. Finally, a sense of confidence in students' abilitiesthat is influenced by the knowledge and skills that they get from EE can strengthen their intention to become entrepreneurs.

This can be shown from the findings at UC that the advanced curriculum of its EE is basicallythe one that attracts people who want to be entrepreneurs to pursue their further education there. This is because the education, especially the Entrepreneurship (E) project, can build students'positive ATE through the way of the lecturers, guest lecturers, and facilitators teach and inspirethem. Students' SN can also be increased through E project and family business course, as it enables a community of classmates that have the same entrepreneurial minded. It creates a network of mutual support from which students can receive support from their parents, mentors, lecturers, and their group friends. Finally, by knowing how to execute a business, or know how to turn business ideas and opportunities into sustainable business / start-ups as what students do in E project, a sense of confidence in students' abilities will be influenced to be greater. The greater the students' PBC, the stronger their intention to start building a business.

\section{Conclusion and Implications}

Based on the results of the research that has been done, the following conclusions are asfollows:

1) Entrepreneurship education does not significantly influence entrepreneurial intentionof business management students at Universitas Ciputra Surabaya.

2) Entrepreneurship education significantly influences attitude toward entrepreneurship ofbusiness management students at Universitas Ciputra Surabaya.

3) Entrepreneurial education significantly influences subjective norms of businessmanagement students at Universitas Ciputra Surabaya.

4) Entrepreneurial education significantly influences perceived behavioural control ofbusiness management students at Universitas Ciputra Surabaya.

5) Attitude toward entrepreneurship significantly influences entrepreneurial intention ofbusiness management student at Universitas Ciputra Surabaya.

6) Subjective norms significantly influence entrepreneurial intention of businessmanagement student at Universitas Ciputra Surabaya.

7) Perceived behavioural control significantly influences entrepreneurial intention ofbusiness management student at Universitas Ciputra Surabaya.

There are several implications that could be applied to achieve an effective way to increase the EI of business management students at Universitas Ciputra Surabaya. Based on the findings and the discussions, the research result implications of EE, ATE, SN, and PBC variables are presented in Table 5. 
Table 5. Research Implications

\begin{tabular}{lll}
\hline \multicolumn{1}{c}{ Variable } & \multicolumn{1}{c}{ Research Findings } & \multicolumn{1}{c}{ Implications } \\
$\begin{array}{l}\text { Entrepreneurs } \\
\text { hip Education } \\
\text { (EE) }\end{array}$ & $\begin{array}{l}\text { The result of this study state that the } \\
\text { direct relationship between EE to EI } \\
\text { shows no significant effect. This } \\
\text { finding reinforces the result of previous } \\
\text { studies by Kusmintarti et al. (2017) and }\end{array}$ & $\begin{array}{l}\text { 1. Based on the research result that shows } \\
\text { that EE does not have any significant } \\
\text { suggests Universitas CiputraSurabaya to } \\
\text { not really concentrate ondeveloping the } \\
\text { theoretical foundation since it isnot the } \\
\text { Pratana and Margunani (2019). }\end{array}$ \\
& $\begin{array}{l}\text { Nevertheless, EE can significantlyand way to build student's EI. } \\
\text { positively influence EI if it is mediated }\end{array}$ & $\begin{array}{l}\text { Therefore, Universitas Ciputra Surabaya } \\
\text { need to focus more to develop the }\end{array}$ \\
& $\begin{array}{l}\text { by ATE, SN, and PBC variables. This } \\
\text { result is supported by Zhang et al. } \\
\text { (2019) and Paray \& Kumar (2020) in method with the help of the } \\
\text { mediation variables as they can bring } \\
\text { contribution to student's EI. }\end{array}$
\end{tabular}
their researchresults.

\begin{tabular}{ll}
\hline $\begin{array}{l}\text { Attitude } \\
\text { toward }\end{array}$ & The result of this study indicates a \\
Entrepreneurs & positive and significant relationship of \\
hip (ATE) & EE to ATE and ATE to EI. ATE is also \\
found out to act as a fullmediator that \\
mediates the relationship between EE \\
and EI. This is in line with the previous \\
studies from Zhang et al. (2019), \\
Paray and Kumar (2020), Sun et al. \\
(2017), and Farooq et al. (2018).
\end{tabular}
(2017), and Farooq et al. (2018).
1. Encourage students to form a habit of reading books, news, and articles about the world of business, both local and international, by establishing an independent learning system before attending classes and holding quizzes as an assessment. The aim is to develop student's interest in entrepreneurship.

2. Providing facilities by creating a new institution at Universitas Ciputra Surabaya, namely a capital loan institution, for students.

1. Hold a business idea pitching program, where

the program invites

family members/friends/people who are considered important by students as participants who will listen to their pitching, in which after the pitching process is done, the students can exchange ideas, share, and discuss their goal with their invited guests.

2. Create a business organization or community (it can be like UCFC or UKM) of students that have the same entrepreneurial minded and vision so that they can discuss about updated market trend and exchange their view and opinion. It can create a network of mutual support from which individuals can receive support from their organizational mentors / facilitators and friends. 


\begin{tabular}{ll}
\hline Perceived & The result of this study indicates a \\
Behavioral & positive and significant relationship of \\
Control (PBC) & EE to PBC and PBC to EI. PBC is also \\
& found out to act as a full mediator that \\
& mediates the relationship between EE \\
& and EI. This is in line with the previous \\
& studies from Zhang et al. (2019), Paray \\
& and Kumar (2020), Sun et al. (2017), \\
& and Farooq et al. (2018).
\end{tabular}

1. Hold seminars, trainings, and workshops about business in terms of the 4 pillars of management (finance, marketing, operations, and human capital). The purpose is to enhance the knowledge and skills for the students not only receive learning material in theories but also learn about how to apply those theories to their business. This can increase their knowledge, abilities and skills at the same time.

2. Teach and train public speaking and negotiation skills to students through $\mathrm{E}$ subject or any other courses with class activities that can be developed by lecturers and facilitators so that students can learn to be confident and be able to negotiate in business.

3. Developing the Leadership 101 program to be more focused in shaping student's competences as a leader in business activities, so that it is not only focused on the context of the leader in committee activities.

Source: Processed data (2020)

There are two limitations in this research. First, this study emphasizes the advanced curriculum of entrepreneurship education at Universitas Ciputra Surabaya. Hence, the concept of entrepreneurship education in this research is not in an introduction or general level only, whichmostly done by many studies. Second, the results of this study indicate that the variables studiedare still very limited because the R2 value in each variable shows less than $50 \%$, which meansthat there are other variables that are more influential than the variables in this study. Future studies can consider examining several other variables that could be more influencing entrepreneurial intention as dependent variable, such as entrepreneurial passion, entrepreneurial personality, entrepreneurial motivation, family background, etc. In addition, ifthe future researchers still want to examine entrepreneurship education as the independent variable, they can involve more specific educational aspects, such as learning design, teachingmethods, facilities provided, campus environment, etc. Further studies can also develop this research by further examining the level of entrepreneurial behavior or entrepreneurial action, because this study only focuses on the level of entrepreneurial intention.

\section{References}

Ajzen, I. (1988). Attitudes, Personality, and Behavior. Chicago: Dorsey Press.

Ajzen, I. (1991). The Theory of Planned Behavior. Organizational Behavior and Human Decision Processes, Vol. 50, No. 2, 179-211.

Basu, A., \& Virick, M. (2008). Assessing Entrepreneurial Intentions Amongst Students: A Comparative Study. 12th Annual Meeting of the National Collegiate Inventors and Innovators Alliance, Dallas, USA, 19-21.

Bui, T. H. V., Nguyen, T. L. T., Tran, M. D., \& Nguyen, T. A. T.T. (2020). Determinants Influencing Entrepreneurial Intention among Undergraduates in Universities of Vietnam,Journal of Asian Finance, Economics and Business, 7(7): 369-378

Do Paco, A. et al. (2011). Behaviours and Entrepreneurial Intention: Empirical Findings About Secondary Students. Journal of International Entrepreneurship, Vol. 9 No. 1, 20-38.

Farooq, M. et al. (2018). Impact of support from social network on entrepreneurial intention of fresh business graduates A structural equation modelling approach. Education + Training, Vol. 60, No. 4, 335-353.

Galloway, L., \& Brown, W. (2002). Entrepreneurship Education at University: A Driver in the Creation of 
High Growth Firms? Education+Training, Vol. 44 No. 8/9, 398-405.

Garson, G. (2016). Partial Least Squares: Regression \& Structural Equation Models. Statistical Associates Publishing.

Gerba, D. (2012). Impact of entrepreneurship education on entrepreneurial intentions of business and engineering students in Ethiopia. African Journal of Economic and Management Studies. Vol. 3, No. 2., 258 - 277.

Hair, Jr., J. et al. (2017). A Primer on Partial Least Squares Structural Equation Modeling (PLS-SEM) Second Edition. Los Angeles: Sage Publication.

Kshetri, N. (2018). Global Entrepreneurship. Global Entrepreneurship. https://doi.org/10.4324/9780429458996

Kuehn, K. (2008). Entrepreneurial intentions research: implications for entrepreneurship education. Journal of Entrepreneurship Education, Vol. 11, 87-98.

Kusmintarti, A., Riwajanti, N. I., \& Asdani, A. (2017). Pendidikan Kewirausahaan dan Intensi Kewirausahaan dengan Sikap Kewirausahaan sebagai Mediasi. Jurnal Riset dan Aplikasi: Akuntansi dan Manajemen, Vol. 2 No. 2, 119-128.Luc,

P. T. (2020). Outcome Expectations and Social Entrepreneurial Intention: Integration of Planned Behavior and Social Cognitive Career Theory. The Journal of Asian Finance, Economics and Business, 7(6): 399-407.

Lu, H., \& Wang, J. (2018). Entrepreneurial Intention of Two Patterns of Planned Behaviour and Alertness: Empirical Evidence in China. The Journal of Asian Finance, Economics and Business, 5(2): 63-72.

Paray, Z., \& Kumar, S. (2020). Does entrepreneurship education influence entrepreneurial intention among students in HEI's? The role of age,gender and degree background. Journal of International Education in Business, Vol. 13 No. 1, 55-72.

Phan, L. T. (2018). The Relationship between Perceived Access to Finance and Social Entrepreneurship Intentions among University Students in Vietnam. Journal of Asian Finance Economics and Business, 5(1), 63-72.

Pratana, N. K., \& Margunani. (2019). Pengaruh Sikap Berwirausaha, Norma Subjektif dan Pendidikan Kewirausahaan Terhadap Intensi Berwirausaha. Economic Education Analysis Journal, Vol. 8 No. 2, 533-550.

Puni, A., Anlesinya, A., \& Korsorku, P. (2018). Entrepreneurial education, self-efficacy and intentions in Sub-Saharan Africa. African Journal of Economic and Management Studies, Vol. 9 No. 4, 492-511.

Rasli, A. et al. (2013). Factors Affecting Entrepreneurial Intention Among Graduate Students of Universiti Teknologi Malaysia. International Journal of Business and Social Science.Vol. 4 No. 2, 182-188 .

Santi, N., Hamzah, A., \& Rahmawati, T. (2017). Pengaruh Efikasi Diri, Norma Subjektif, Sikap Berperilaku, dan Pendidikan Kewirausahaan Terhadap Intensi Berwirausaha. Jurnal Inspirasi Bisnis dan Manajemen, Vol. 1 No. 1, 63-74.

Schwarz, E. et al. (2009). The effects of attitudes and perceived environment conditions on students' entrepreneurial intent: an Austrian perspective. Education Training, Vol. 51 No. 4, 272-291.

Sekaran, U., \& Bougie, R. (2016). Research Method for Business: A Skill-Building Approach Seventh Edition. Chichester UK: John Wiley \& Sons Ltd.

Souitaris, V., Zerbinati, S., \& Al-Laham, A. (2007). Do entrepreneurship programmes raise entrepreneurial intention of science and engineering students? The effect of learning, inspiration and resources. Journal of Business Venturing, Vol. 22 No. 4, 566-591.

Sun, H. et al. (2017). The impact of entrepreneurial education on entrepreneurial intention of engineering students in HongKong. Management Decision, Vol. 55 No. 7, 1371-1393.

Thompson, E. (2009). Individual entrepreneurial intent: construct clarification and development of an internationally reliable metric. Entrepreneurship Theory and Practice, Vol. 33 No. 3, 669-694.

Utami, C. W. (2017). Attitude, Subjective Norms, Perceived Behavior, Entrepreneurship Education and Self-efficacy toward Entrepreneurial Intention University Student in Indonesia . European Research Studies Journal Volume XX, Issue 2A, 475-495.

Wilson, F., Kickul, J., \& Marlino, D. (2007). Gender, entrepreneurial self-efficacy, and entrepreneurial career intentions: implications for entrepreneurship education. Entrepreneurship Theory and Practice, Vol. 31 No. 3, 387-406.

Zhang, F. et al. (2019). How entrepreneurial learning impacts one's intention towards entrepreneurship: A planned behavior approach. Chinese Management Studies, Vol. 13 No. 1, 146-170. 